\title{
高弾性合金“Dia-flex”単結晶の弾性係数 の異方性ならびにその温度変化
}

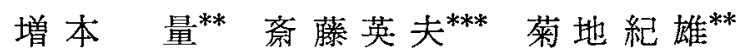

Hakaru Masumoto, Hideo Saitô and Michio Kikuchi : On the Elastic Anisotropies and its Temperature Change of Single Crystals of High Elasticity Alloy "Dia-flex" in the Co$\mathrm{Fe}-\mathrm{Ni}-\mathrm{Cr}-\mathrm{W}-\mathrm{Mo}$ System. The thermal expansion in the temperature range of $0^{\circ}$ to $800^{\circ} \mathrm{C}$, Young's modulus in the temperature range of $-50^{\circ}$ to $300^{\circ} \mathrm{C}$, rigidity modulus in the temperature range of $10^{\circ}$ to $50^{\circ} \mathrm{C}$ and the mechanical strength at room temperature in a high elasticity alloy of F.C.C. type "Dia-flex" consisting of $38.0 \% \mathrm{Co}, 22.4 \% \mathrm{Fe}, 16.5 \% \mathrm{Ni}, 12.0 \% \mathrm{Cr}, 4.0 \% \mathrm{~W}, 4.0 \% \mathrm{Mo}$ and small amounts of other elements were measured with the single crystals and annealed poly-crystals (in the predominant direction $\langle 112\rangle(1 \overline{1} 0)$ : Young's molulus $23.00 \times 10^{5} \mathrm{~kg} / \mathrm{cm}^{2}$, elastic 1 imit $120 \mathrm{~kg} / \mathrm{mm}^{2}$ and tensile strength $250 \mathrm{~kg} /$ $\left.\mathrm{mm}^{2}\right)$. Then, from the data obtained, the volume compressibility, the principal elastic parameters $S_{i j}$, the principal elastic constants $\mathrm{C}_{i j}$, and Young's modulus and the rigidity modulus in three principal orientations of the single crystals were calculated. From the result it has been known that Young's moduli at $20^{\circ} \mathrm{C}$ are $11.68 \times 10^{5} \mathrm{~kg} / \mathrm{cm}^{2}, 22.49 \times 10^{5} \mathrm{~kg} / \mathrm{cm}^{2}$ and $33.78 \times 10^{5} \mathrm{~kg} / \mathrm{cm}^{2}$, and the rigidity moduli at $20^{\circ} \mathrm{C}, 12.01 \times 10^{5} \mathrm{~kg} / \mathrm{cm}^{2}, 5.93 \times 10^{5} \mathrm{~kg} / \mathrm{cm}^{2}$ and $5.33 \times 10^{5} \mathrm{~kg} / \mathrm{cm}^{2}$ respectively in the orientations of $\langle 100\rangle,\langle 110\rangle$ and $\langle 111\rangle$ of the single crystals, showing high anisotropies of elastic moduli. The anisotropy of the temperature coefficients of elastic moduli is also very high.

(Received September 7, 1966)

\section{I. 緒 言}

一般に時計の動力ゼンマイなどは高い引張強さ，高い弾 性限，高い耐食性などを必要とし，その材料としては，現

** 財団法人, 電気磁気材料研究所(The Foundation: The Research Institute of Electric and Magnetic Alloys, Sendai)

*** 東北大学金属材料研究所 (The Research Institute for Iron, Steel and Other Metals Tôhoku University, Sendai)

* 1964 年 10 月本会富山大会に発表; 財団法人，電気 磁気材料研究所論文 No.15.
在多くは適当们工熱処理された $\mathrm{Co}, \mathrm{Fe}, \mathrm{Ni}, \mathrm{Cr}, \mathrm{W}, \mathrm{Mo}$ ぞを主成分とする合金 (たと点ばElgiloy(1))，すなわち多 元系面心立方格子型合金が使用されている，むちろんこれ らの合金も結晶異方性が大きいので，その優位力向ができ るだけ使用方向に一致するよ5に加工方法や熱処理法につ いても従来多くの研究が行なわれている(2). しかし単結晶

(1) 米 Elgin 社製 $40 \mathrm{Co}-25 \overline{\mathrm{Cr}}-22 \mathrm{Ni}-0.03 \mathrm{Be}-(0.15 \sim$ $0.20) \mathrm{C}-2 \mathrm{Mn}-\mathrm{Bal}$. Fe 合金

(2) M.F.Straumann: Soc. Suisse de Chronom., (1954), 209 ; M.E.Dubois : Soc. Suisse de Chronom., (1954), 215; 任藤, 池田,鎌田：日本時計学会誌, 12 (1961), 39 など・ 
によつて弾性係数とその異方性を決定した例はまだないよ らに思われる。よつて著者らは Co-Fe-Ni-Cr-W-Mo 系高 弾性合金“Dia-flex”(3)（使用状態に拈けるヤング弾性率は $23.00 \times 10^{5} \mathrm{~kg} / \mathrm{cm}^{2}$, 弾性限は $120 \mathrm{~kg} / \mathrm{mm}^{2}$, 引張強さは 250 $\mathrm{kg} / \mathrm{mm}^{2}$ である) の単結晶を製造し, 焼鈍状態に拈けるヤ ング弾性率とその温度変化を測定した．さらにこれに基づ いて種ふの理論式から多結晶に対するヤング弾性率を計算 して実測值と比較した. また室温付近の剛性率をも測定し て弾性常数を求めた.

\section{II. 試 料および測 定方 誌}

\section{1. 試 料}

単結晶は $38.0 \% \mathrm{Co}, 22.4 \% \mathrm{Fe}, 16.5 \% \mathrm{Ni}, 12.0 \% \mathrm{Cr}$, $4.0 \% \mathrm{Mo}, 4.0 \% \mathrm{~W}, 1.2 \% \mathrm{Mn}, 1.0 \% \mathrm{Ti}$ 扎よび $0.8 \% \mathrm{Si}$ から成る高弾性合金の直径 $2 \mathrm{~mm}$ の線材を内径 $3 \mathrm{~mm}$ の特 殊ルッボ中に入れ，真空中で溶かし，タンマンーブリッジ

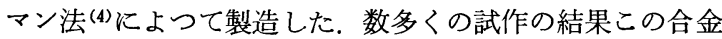
でも通常の面心立方格子合金の場合と同様に，最も得やす い方位は $\langle 100\rangle$ 方向 ${ }^{(5)}$ で，単結晶成長の最適降下速度は $5.0 \mathrm{~mm} / \mathrm{min}$ であることが判つた.しかし $<110\rangle,\langle 111\rangle$ 方向の結晶を得ることはこの方法だけでは非常に困難で京 つたので，これに $\langle 100\rangle$ 結晶を適当な角度で種として接 ぎ，結晶を成長させた。その最適降下速度はそれぞれ 4.0 $\mathrm{mm} / \mathrm{min}, 3.7 \mathrm{~mm} / \mathrm{min}$ であつた。この方法で造つた単結 晶は上きどき内部に気泡などを含むこともあるので，密度 を測定してその固有つ值からはずれるものは測定うら除外 した. かくして長さ $15 \sim 20 \mathrm{~cm}$, 直径 $3 \mathrm{~mm}$ 程度の円壔状 の単結晶を筡造することができたが，測定の都合上試料の 長さはすべて $12 \mathrm{~cm}$ に統一した。 その結晶方位は試料を沸 騰した塩化䈍二鉄過飽和溶液に. 10 分間,または稀薄王水に 2 分間浸漬腐食して光像法 ${ }^{(4)}{ }^{(6)}$ によつて決定した。 また直 径約 $3 \mathrm{~mm}$ の多結晶試料の弾性係数执よび直径約 $0.5 \mathrm{~mm}$ の多結晶試料の剛性率を測定したが，いずれの場合にも準 等方的な試料を得るこめに溶融合金を結晶の成長しない程 度の速さで凝固させ心.つぎに試料はすべて歪を除くため に真空中で再結晶の起らな!温度 $800^{\circ} \mathrm{C}$ で約 $1 \mathrm{hr}$ 焼鈍し た. 製造し心全単結晶試料のステレオ投影(7)による方位分 布はFig.1に示すと拉りでする.図中番号を付した試料の みが測定に供され，その方位は Table 1 にまとめてある。

\section{2. 測 定 方 法}

熱膨張の測定は Super-Invar 製縦型全膨張計 ${ }^{(8)}$ および横

（3）増本, 斎藤, 小林：日本特許第 230713 号 (炤和 31 年 12 月 14 日)

（4）山本：東北帝大理科報告, $29(1940), 113$; 本 誌, 4 (1940), ,368.

(5) 山本：本誌, $4(1940), 27,168,222$.

(6) 山本: 本誌, 5(1941), 214 ; 応用物理, 10 (1940), 199.

(7) 山本：金属物理, 6(1960), 118; C.S. Barett : The Stereographic Projection, AIME Techn. Publ., No. 819 (Met. Techn., 4 (1937), No.5) .
型全膨張計により $0^{\circ} \sim 800^{\circ} \mathrm{C}$ の範囲で行なつて平均の線膨 張係数を定め, 密度は水中秤量法によつて求めた. ヤング

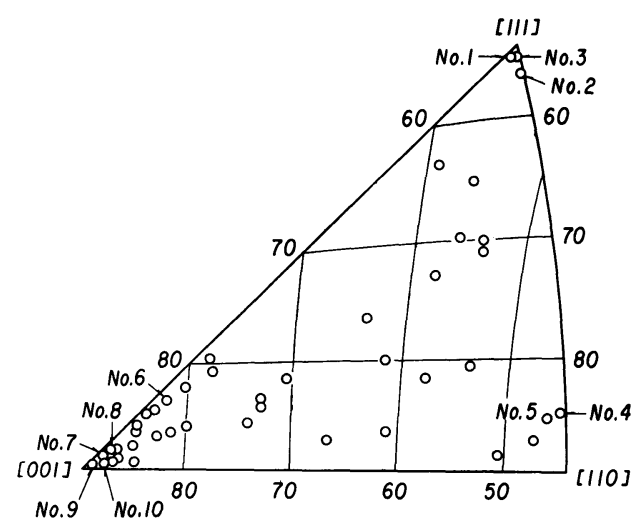

Fig.1 Stereographic projection of orientation of single crystals of the $\mathrm{Co}-\mathrm{Fe}-\mathrm{Ni}-\mathrm{Cr}$ W-Mo alloy (Specimen No.1 10).

Table 1 Direction consines of the rod axis of single crystals of the $\mathrm{Co}-\mathrm{Fe}-\mathrm{Ni}-\mathrm{Cr}-\mathrm{W}-\mathrm{Mo}$ alloy used.

\begin{tabular}{c|c|c|c}
\hline Specimen No. & $\alpha_{1}$ & $\alpha_{2}$ & $\alpha_{3}$ \\
\hline 1 & 54.21 & 55.30 & 48.28 \\
2 & 54.00 & 56.30 & 47.52 \\
3 & 55.30 & 55.30 & 53.14 \\
4 & 45.30 & 84.30 & 45.02 \\
5 & 46.25 & 85.00 & 44.02 \\
6 & 82.30 & 83.50 & 9.58 \\
7 & 88.30 & 89.00 & 1.48 \\
8 & 87.00 & 88.30 & 2.48 \\
9 & 89.00 & 89.50 & 1.06 \\
10 & 89.00 & 89.00 & 1.31 \\
\hline
\end{tabular}

弾性率は静電駆動方式(9) の装置により $-50^{\circ} \sim 300^{\circ} \mathrm{C}$ の温 度で試料の固有振動数 $(600 \sim 800 \mathrm{c} / \mathrm{s})$ を求め, 熱膨張係数 および密度の測定值を用いて算出した。つぎに剛性率の測 定は直径 $0.5 \mathrm{~mm}$ の多結晶試料を用い摸り振子法(10)によ り $10^{\circ} \sim 50^{\circ} \mathrm{C}$ で行なつた. 引張強さは焼鈍状態の試料を用 いインストロン試験機によつて荷重 $200 \mathrm{~kg}$ から最大 2000 $\mathrm{kg}$ の範囲で測定した.

\section{III. 研究結果ならびに考察}

\section{1. 熱 膨 張}

$\langle 100\rangle$, $\langle 110\rangle$ 执よび $\langle 111\rangle$ 方向に最も近い方位を もつ 3 ケの試料について $0^{\circ} \mathrm{C}$ から $800^{\circ} \mathrm{C}$ までの範囲で行 なつた熱膨張の 測定結果は Fig. 2 に示してある. 図に見 るよ5に熱膨張は全く等方的でいずれの方位の曲線も558 ${ }^{\circ} \mathrm{C}$ に明瞭な折点を示す。これはわずかに残存する磁気が この温度で消失するためではないかと思われる，またこの

(8) 増本, 小林: Sci. Rep. RITU, A 2 (1950), 856; 本 誌, 12 (1948) ,No.6-1.

（9）白川, 小熊：本誌, $24(1960), 63$.

(10) 増本, 斎藤: 本誌, $16(1952), 126 ;$ P. Chevenard: Trav. et Mém du Bur. Int. des Poids et Mesures, 17 (1927) , 44. 
折点の両側における曲線はほとんど直線で，低温側におけ る線膨張係数は $13.40 \times 10^{-6}$, 高温側に拈ける值は $15.71 \times$

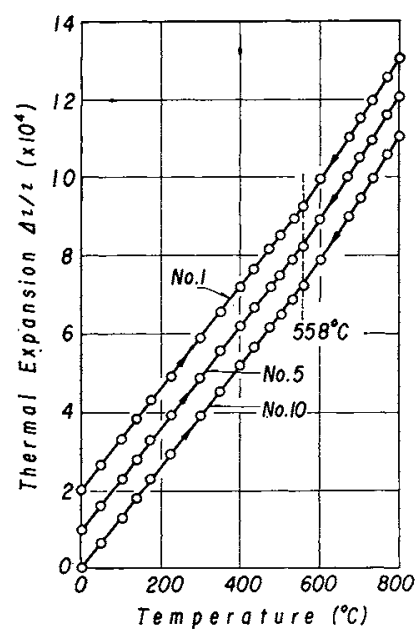

Fig. 2 Thermal expansion $\Delta l / l$ of single crystals of the Co-Fe-Ni-Cr-W-Mo alloy.

10-6 となる。これらの值は多結晶試料についてる同様で まる。

\section{2.ヤンク弾性事ならびに剛性率}

Fig.3 はヤング弾性率 $E$ の実測値と温度との関係を示 すが，Eの異方性は非常に大さい。しかしこれらの実測值 だけでは任意の方向の值を知ることがでさないので，等軸 晶系結晶に関するつぎの計算式(11)によつてこれを求める ことにする。

$$
\frac{1}{E}=S_{11}-2\left(S_{11}-S_{12}-\frac{1}{2} S_{44}\right)\left(\alpha_{1}^{2} \alpha_{2}^{2}+\alpha_{2}^{2} \alpha_{3}^{2}+\alpha_{\left.3^{2} \alpha_{1}^{2}\right)}\right.
$$

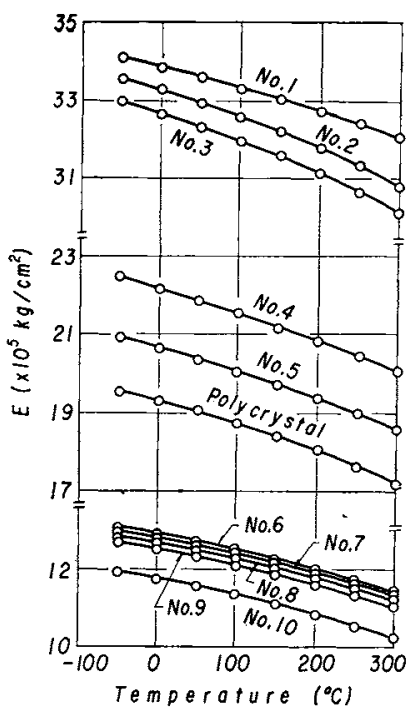

Fig.3 Temperature change of Young's modulus $E$ of single crystals and a poly-crystal of the $\mathrm{Co}-\mathrm{Fe}-\mathrm{Ni}-\mathrm{Cr}-\mathrm{W}-\mathrm{Mo}$ alloy.

(11) W. Voigt : Lehrbuch der Kristallphysik (B. G. Teubner Leipzig) $,(1928), 739,741,410 ;$ W.A. Wooster: Crystal Physics (Cambridge), (1938), 1 .
ここに $S_{i j}$ は弾性パラメーターで， $\alpha_{i} \alpha_{j}$ は結晶軸に対する 棒軸の力向余弦である．また $\sum \alpha_{i}^{2} 2 \alpha_{j}^{2}$ は方向函数で，その

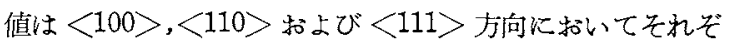
れ 0,1/4,1/3 となる. Fig.4は 1/Eと $3 \sum \alpha_{i}^{2} \alpha_{j}{ }^{2}$ の関係を

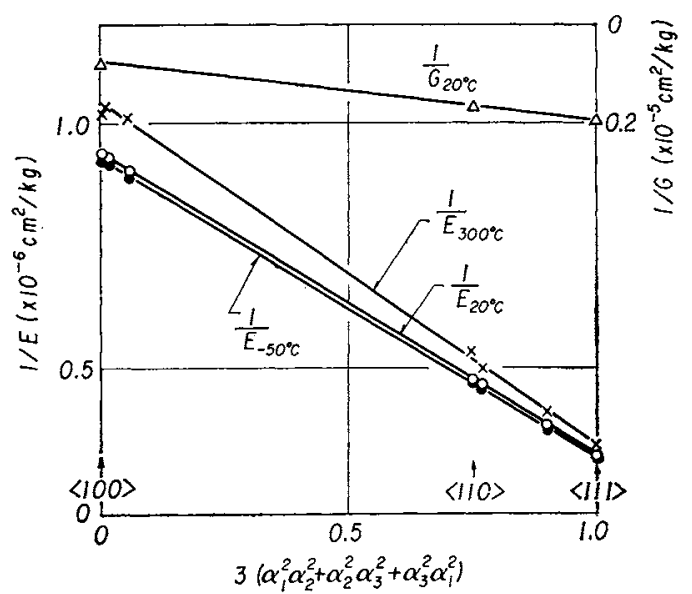

Fig.4 Relations between reciprocals of Young's modulus $E$ and rigidity modulus $G$ and the orientation function $3\left(\alpha_{1}{ }^{2} \alpha_{2}{ }^{2}+\alpha_{2}{ }^{2} \alpha_{3}{ }^{2}\right.$ $\left.+\alpha_{3}^{2} \alpha_{1}^{2}\right)$ of single crystals of the $\mathrm{Co}-\mathrm{Fe}-$ $\mathrm{Ni}-\mathrm{Cr}-\mathrm{W}-\mathrm{Mo}$ alloy.

表わしたもので，測定点はほぼ值線上化乗る、したがつ て式(1) が正しいすのとして $E$ の実測值を用い最小二乗 法によつて $S_{11}$ 扰よび $S_{11}-S_{12}-(1 / 2) S_{44}$ の值を求めるこ とができる，さらに，3主要軸を含む (110) 面内での $\mathrm{E} の$ 值を計算する。この面では

$$
\left(\alpha_{1}^{2} \alpha_{2}^{2}+\alpha_{2}^{2} \alpha_{3}^{2}+\alpha_{3}^{2} \alpha_{1}^{2}\right)=\frac{1}{4}\left(1+2 \cos ^{2} \theta-3 \cos ^{2} \theta\right)
$$

である.ここに $\theta$ は [001] 万向と試料の棒軸との角度であ る.式(1)にこれを適用して任意の力向の $E$ を計算するこ とができる，いま計算によつて求めた $S_{11}$ および $S_{11}-S_{12}$ $(1 / 2) S_{44}$ と温度との関俰， 3 主要方向に対する $E$ と温度と の関係扣よび $(110)$ 面上に打ける $-50^{\circ}, 20^{\circ}$ 牤よび $300^{\circ} \mathrm{C}$

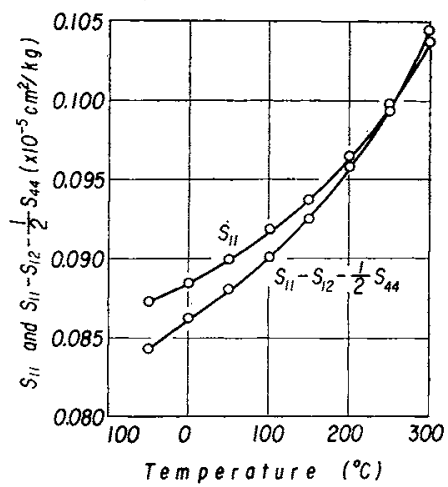

Fig.5 Temperature change of calculated values of elastic parameters $S_{11}$ and $S_{11}-S_{12}$ (1/2) $S_{44}$ of single crystals of the Co-Fe$\mathrm{Ni}-\mathrm{Cr}-\mathrm{W}-\mathrm{Mo}$ alloy.

の温度の $E$ と方位との関倸を示示と，それぞれ Fig.5, Fig. 6 およびFig.7 のよ5になる。すなわち $E$ は Fig.6 
にみる上うにどの方向でも $-50^{\circ} \mathrm{C} か ら 20^{\circ} \mathrm{C}$ 付近までは ほぼ直線的に，ついで扰物線的に減少しいずれの温度に拉

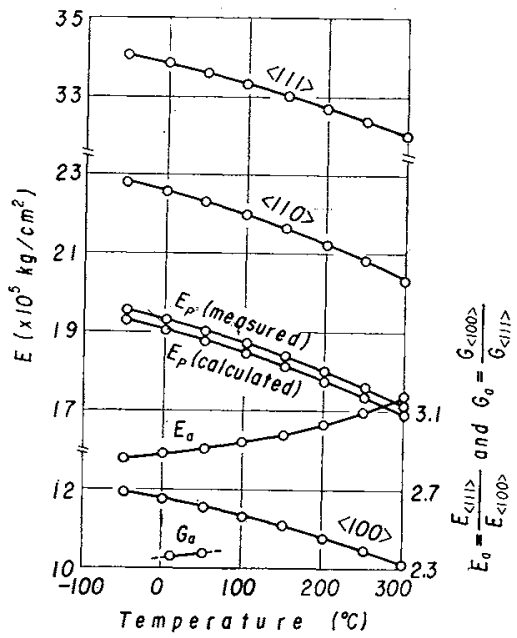

Fig.6 Temperature change of calculated values of Young's modulus $E$ in three principal orientations of single crystals and a polycrystal of the $\mathrm{Co}-\mathrm{Fe}-\mathrm{Ni}-\mathrm{Cr}-\mathrm{W}-\mathrm{Mo}$ alloy, and elastic anisotropies $E_{a}\left(E_{<111>}\right)$ $\left.E_{<100>}\right)$ and $G_{a}\left(G_{<100>} / G_{<111}\right)$.

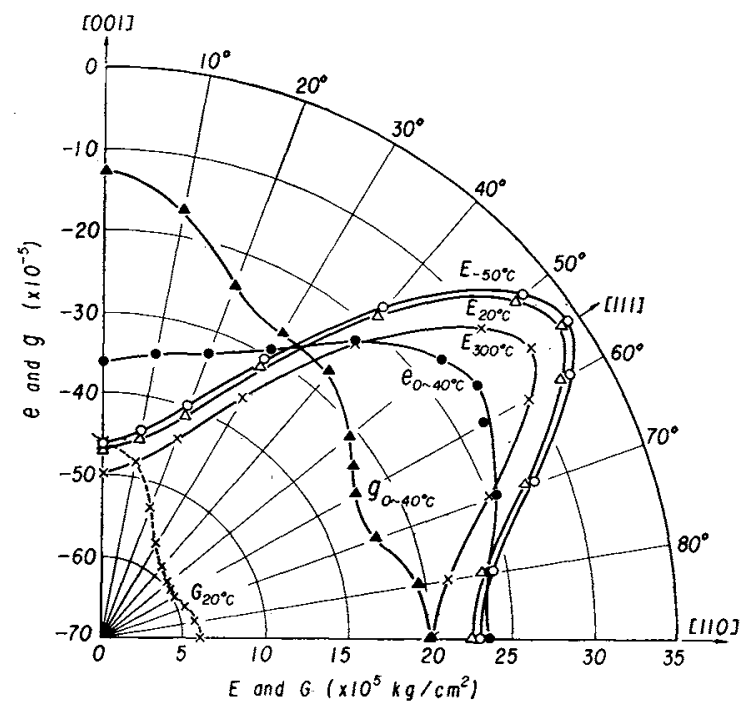

Fig.7 Calculated values of Young's modulus $E$, rigidity modulus $G$ and their temperature coefficients e and $g$ of various orientations in (110) plane of single crystals of the $\mathrm{Co}-\mathrm{Fe}-\mathrm{Ni}-\mathrm{Cr}-\mathrm{W}-\mathrm{Mo}$ alloy .

いても<111 >方向で最大值をとり，〈100>方向で最小 值を示す。すなわち等軸晶系に捛ける各主要方位のヤング 弾性率間の関保式

$$
E_{<111>}>E_{<110>}>E_{<100>}
$$

によく合致する。とくにく 111$\rangle$ 方向の $E$ は $33.78 \times 10^{5}$ $\mathrm{kg} / \mathrm{cm}^{2}\left(20^{\circ} \mathrm{C}\right)$ なる值を示し, 現在市販の動力ゼンマイが 長手方向以主として<112>(110) 方向をむちその $E$ の值 が $23.00 \times 10^{5} \mathrm{~kg} / \mathrm{cm}^{2}(2)$ であることを考市あわせると応用

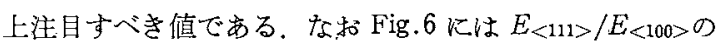
温度による变化も曲線で示して执いたが，普通の $f c c$ 純金 属に比べてかなり大きく(12) $20^{\circ} \mathrm{C} て ゙ 2.89$ で，300年では

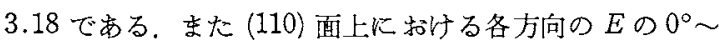
$40^{\circ} \mathrm{C}$ での平均温度保数, $e^{\circ} \sim 40^{\circ} \mathrm{C}$ は Fig. 7 V, 各主要軸方 向の $0^{\circ} \sim 40^{\circ} \mathrm{C}$ 括上び $-50^{\circ} \sim 300^{\circ} \mathrm{C}$ での平均温度係数は

Table 2 Calculated values of Young's modulus E, rigidity modulus $\mathrm{G}$ and their temperature coefficients $\mathrm{e}$ and $g$ in three principal orientations of single crystals and volume compressibility $\kappa$ of the Co$\mathrm{Fe}-\mathrm{Ni}-\mathrm{Cr}-\mathrm{W}-\mathrm{Mo}$ alloy.

\begin{tabular}{|c|c|c|c|c|c|c|}
\hline & $\mid \begin{array}{c}E \\
(\ll 10\end{array}$ & $\begin{array}{c}\mathrm{G} \\
5 \mathrm{~kg} / \\
\left.\mathrm{cm}^{2}\right)\end{array}$ & $\mid \begin{array}{c}\kappa \\
\left(\times 10^{-5} \mathrm{~cm}^{2}\right. \\
\mathrm{kg})\end{array}$ & & $\begin{array}{l}\text { e } \\
\left(\times 10^{-5}\right)\end{array}$ & $\mathrm{g}$ \\
\hline & \multicolumn{3}{|c|}{$20^{\circ} \mathrm{C}$} & $\begin{array}{l}0^{\circ} \widetilde{ } \\
40^{\circ} \mathrm{C}\end{array}$ & $\begin{array}{l}50^{\circ} \sim \\
300^{\circ} \mathrm{C}\end{array}$ & $\begin{array}{l}0^{\circ} \widetilde{ } \\
40^{\circ} \mathrm{C}\end{array}$ \\
\hline $\begin{array}{r}<100> \\
<110\rangle \\
<111>\end{array}$ & $\mid \begin{array}{l}11.68 \\
22.49 \\
33.78 \\
18.99\end{array}$ & $\begin{array}{r}12.01 \\
5.93 \\
5.33 \\
6.50\end{array}$ & $\begin{array}{l}\overline{-} \\
\overline{0.0270}\end{array}$ & $\begin{array}{l}-36.20 \\
-23.25 \\
-14.76 \\
-18.22\end{array}$ & $\mid \begin{array}{l}-39.32 \\
-29.26 \\
-20.16 \\
-30.48\end{array}$ & \begin{tabular}{|l}
-12.73 \\
-29.27 \\
-29.38 \\
-28.40
\end{tabular} \\
\hline
\end{tabular}

Table 2 にまとめてある。

つぎに準多結晶体に対するヤング弹性率の值は，すべて の結晶粒に乱昰力状態が等しいと仮定して歪力成分 $S_{i j}$ の平均を用いると，Reuß(13) にしたがつて

$$
E_{p}=\frac{5}{3 S_{11}+2 \overline{S_{12}}+S_{44}}
$$

で与兄られる。この式によつて計算した $E_{p}$ (calculated) の 值と溶融後徐洛した準多結晶陚料について実測した $E_{p}$ (measured)の値とを比較するとFig.6のようになるが，両 者はほとんど一致しておる。

つぎに測定した沺性率 $G$ の温度変化の模様はFig.8 亿 示すよ5に $E$ の場合と同様直線的江減少する.室温での $G$

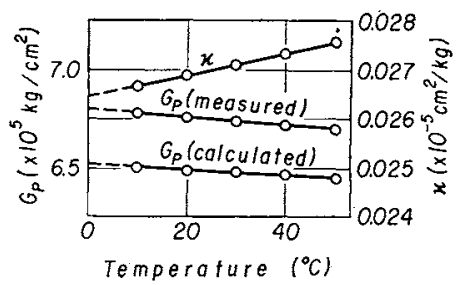

Fig.8 Temperature change of measured and calculated values of rigidity modulus $G$ and calculated values of volume compressibility $\kappa$ of the $\mathrm{Co}-\mathrm{Fe}-\mathrm{Ni}-\mathrm{Cr}-$ W-Mo alloy.

およびその温度係数 $g$ は Table 2 に示すと拈りである。

さて, 弾性パラメーターを全部決定するにはまづ体圧䧽 率 を知らねばならぬ。多結晶試料の $\kappa$ と $E$ 和よび $G$ と の間には

$$
\kappa=\frac{3(3 G-E)}{E G}
$$

(12) 山本：本誌，6(1942)，331 たとえば Fe, Ni につい て比較されたい.

(13) A. ReuB: Z. angew. Math. u. Mechn., 9 (1929), 49. 
なる関係式があるので，これによつてぇを求めると Table 2 に示亦値となる。をた $\kappa$ と $S_{i j}$ との間には

$$
\kappa=3\left(S_{11}+2 S_{12}\right)
$$

なる関係式が成立つので，まづFig.5 に示す $S_{11}$ の值を用 いて $S_{12}$ を求め, さらに同図に示す $S_{11}-S_{12}-(1 / 2) S_{44}$ の值 から $S_{44}$ を計算しこれらの值を Table 3 にまとめて括い

Table 3 Calculated values of elastic parameters $S_{i j}$ and elastic constants $C_{i j}$ at $0^{\circ}$ and $50^{\circ} \mathrm{C}$ of the $\mathrm{Co}-\mathrm{Fe}-\mathrm{Ni}-\mathrm{Cr}-\mathrm{W}-\mathrm{Mo}$ alloy.

\begin{tabular}{r|r|r|r|r|r}
\hline & \multicolumn{2}{|c|}{$\left(\times 10^{-5} \mathrm{~cm}^{2} / \mathrm{kg}\right)$} & & \multicolumn{2}{c}{$\left(\times 10^{5} \mathrm{~kg} / \mathrm{cm}^{2}\right)$} \\
\cline { 2 - 6 } & \multicolumn{1}{|c|}{$0^{\circ} \mathrm{C}$} & $50^{\circ} \mathrm{C}$ & & $C^{\circ} \mathrm{C}$ & $50^{\circ} \mathrm{C}$ \\
\hline$S_{11}$ & 0.0889 & 0.0902 & $C_{11}$ & 42.51 & 41.41 \\
$S_{12}$ & -0.0400 & -0.0405 & $C_{12}$ & 34.77 & 33.75 \\
$S_{44}$ & 0.0849 & 0.0853 & $C_{44}$ & 17.78 & 11.72 \\
\hline
\end{tabular}

た。ささらに主要弾性常数 $C_{i j}$ を求めるにはつぎの関係式(11) を用いればよい。

$$
\begin{aligned}
& C_{11}=\frac{S_{11}+S_{12}}{\left(S_{11}-S_{12}\right)\left(S_{11}+2 S_{12}\right)} \\
& C_{12}=\frac{-S_{12}}{\left(S_{11}-S_{12}\right)\left(S_{11}+2 S_{12}\right)} \\
& C_{44}=-\frac{1}{S_{44}}
\end{aligned}
$$

これによつて計算された $0^{\circ} \mathrm{C}$ 括よび $50^{\circ} \mathrm{C} の C_{i j}$ の值は Table 3 にま之めてあるか，立方晶系に拈けるCauchy の 関係 $C_{12}=C_{44}{ }^{(14)}$ は全く成立しないことがわかる(15)。つき に等軸晶系に执いて主要軸方向に詨する晭栍率 $G$ と $S_{i j}$ と の間には

$$
\begin{aligned}
\frac{1}{G}=S_{44}+4 & \left(S_{11}-S_{12}-\frac{1}{2} S_{44}\right) \\
& \times\left(\alpha_{1}^{2} \alpha_{2}{ }^{2}+\alpha_{2}^{2} \alpha_{3}{ }^{2}+\alpha_{3}^{\left.2 \alpha_{1}{ }^{2}\right)}\right.
\end{aligned}
$$

なる関係があるのでこれに前に求めた $S_{i j}$ の值を代入すれ ば種々な方位执よび温度に対する $G$ を求めることができ る. その計算の結果はFig. 7 および Table 2 に示してか る、すなわら $G$ は $<100>$ 方向で最大で，〈111>方向で 最小である。このことは同じく立方晶の Fe あるいはNiで も同様である(12)，20ㄷ における $1 / G$ と方向函数との関係 はFig. 4 に示したが，その曲線は当然一直線である。

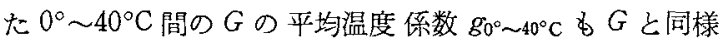
$\langle 100\rangle$ 方向で最大を示し，〈111>方向で最小を示生。 $G$ の異方性 $G<100>/ G<111>$ は広い温度範囲で澌ることは できなかつたが，Fig.6亿示すよ 5 に $20^{\circ} \mathrm{C} た 2.36,50^{\circ} \mathrm{C}$ で 2.38 で高温になるにしたがつて $E$ と同様漸堌する傾向 にある，つぎに多結晶に対する $G$ の值 $G_{p}$ は $S_{i j}$ との閒に 次式(13) 加成立する。

(14) たとえば(11)で410。

(15) Al で G.N.Kamm and G.A.Alers: J.Appl. Phys., $35(1964), 327$; Fe-Ni で G. A. Alers and J. R. Neighbours: J.Phys. Chem. Solids, $13(1960), 40$; Ta,W,Mo で F.M.Featherston and I.R. Neighbours: Phys. Rev., 130(1963),1324; その他種々比較した 6のとして R.F.S.Hearmon: Rev. Mod. Phys., 18 $(1946), 432$.

$$
G_{p}=\stackrel{5}{4} S_{11}-4 S_{12}+3 S_{44}
$$

この式によつて計算した $G_{p}$ はFig. 8 に示してあるが，溶 解によつて得た試料の測定結果と大差はない.

\section{3. 機械的強度}

$\langle 100\rangle$ に近い方向を有する No.9，〈110>に近い方向 を有する No.4，〈111〉に近い方向を有するNo.2 拉よび 多結晶の焼鈍状態に括ける $20^{\circ} \mathrm{C}$ の弾泩限, 降伏点, 引張 強さを測定して Table 4 の值を得た。表でみるように

Table 4 Mechanical properties of single crystals and a poly-crystal of the $\mathrm{Co}-\mathrm{Fe}-\mathrm{Ni}-\mathrm{Cr}-$ W-Mo alloy.

\begin{tabular}{c|c|c|c}
\hline $\begin{array}{c}\text { Specimen } \\
\text { No. }\end{array}$ & $\begin{array}{c}\text { Elastic limit (perma- } \\
\text { nent strain, 0.003\%) } \\
\left(\mathrm{kg} / \mathrm{mm}^{2}\right)\end{array}$ & $\begin{array}{c}\text { Yield point } \\
\left(\mathrm{kg} / \mathrm{mm}^{2}\right)\end{array}$ & $\begin{array}{c}\text { Tensile } \\
\text { strength } \\
\left(\mathrm{kg} / \mathrm{mm}^{2}\right)\end{array}$ \\
\hline 9 & 21.40 & 24.65 & 40.80 \\
4 & 18.60 & 18.93 & 34.00 \\
2 & 22.01 & 26.27 & 45.27 \\
Poly-crystal & 19.10 & 19.20 & 35.70 \\
\hline
\end{tabular}

$<111>$ 軸に近い方向の值は他の軸に比して最高の值を示 している.

\section{IV. 繶括}

タンマンーブリッジマン法によつて造つた Co-Fe-Ni-CrW-Mo 系高弾性合金 “Dia-flex” の棒状 単結晶について, $800^{\circ} \mathrm{C}$ から 徐冷した状態で $0^{\circ} \sim 800^{\circ} \mathrm{C}$ の熱膨張， $-50^{\circ} \sim$ $300^{\circ} \mathrm{C}$ のヤング弾性率, $10^{\circ} \sim 50^{\circ} \mathrm{C}$ の剛性率执よび室温の 機械的性質を湘定してつぎの結果を得た。

(1) 単結晶を成長させるための最適降下速度は $<100>$, 〈110〉和よびく111〉方向でそれぞれ 5.0,4.0,3.7 mm/ $\min$ である。

（2）単結晶について $0^{\circ} \sim 800^{\circ} \mathrm{C}$ 間で求めた熱膨張曲線は

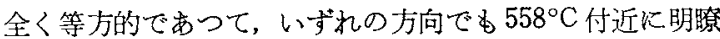
な折点を示す，その折点上下の温度範囲に蚂りる泙均線膨 張係数はそれぞれ $15.71 \times 10^{-6}$ 抢よび $13.40 \times 10^{-6}$ でする。

(3) 計算による 3 主要軸方向 および多結晶体のヤング 弾性率は $20^{\circ} \mathrm{C}$ でれぞれ $E_{<100>}=11.68 \times 10^{5} \mathrm{~kg} / \mathrm{cm}^{2}$, $E_{<110>}=22.49 \times 10^{5} \mathrm{~kg} / \mathrm{cm}^{2}, E_{<111>}=33.78 \times 10^{5} \mathrm{~kg} / \mathrm{cm}^{2}$ 物よび $E_{p}=18.99 \times 10^{5} \mathrm{~kg} / \mathrm{cm}^{2}$ で， $E_{p}$ の值は実測值とは とんど一致する，また $E<111>/ E<100>$ は $20^{\circ} \mathrm{C} て ゙ 2.89$ ， $300^{\circ} \mathrm{C}$ で 3.18 で, 温度とともに増加する。

(4) ヤング弾性率の温度変化の模様は各方位とも互に類 似しており，3主要軸方向就よ゙多結晶体に敊ける $0^{\circ}$ $40^{\circ} \mathrm{C}$ の平均温度係数はそれぞれ $e<100>=-36.20 \times 10^{-5}$, $e_{<110>}=-23.25 \times 10^{-5}, e_{<111>}=-14.76 \times 10^{-5}$ および $e_{p}=$ $-18.22 \times 10^{-5}$ でする.

(5) $20^{\circ} \mathrm{C}$ における主要弾性パラメーターは $S_{11}=0.0894$ $\times 10^{-5}, S_{12}=-0.0402 \times 10^{-5}, S_{44}=0.0850 \times 10^{-5} \mathrm{~cm}^{2} / \mathrm{kg}$ で 㐫る。 
(6) $20^{\circ} \mathrm{C}$ に扣ける主要弾性裳数は $C_{11}=42.09 \times 10^{5}$, $C_{12}=34.35 \times 10^{5}, C_{44}=11.75 \times 10^{5} \mathrm{~kg} / \mathrm{cm}^{2}$ でこの合金では $C_{12}=C_{44}$ なる Cauchy の関係は成立しない.

(7) 計算による3主要軸力向敊よび多結晶体の剛性率は $20^{\circ} \mathrm{C}$ でそれ゙れ $G_{<100>}=12.01 \times 10^{5} \mathrm{~kg} / \mathrm{cm}^{2}, G_{<110>}=$ $5.93 \times 10^{5} \mathrm{~kg} / \mathrm{cm}^{2}, G_{<111>}=5.33 \times 10^{5} \mathrm{~kg} / \mathrm{cm}^{2}$ 㸝よび $G_{p}=$ $6.50 \times 10^{5} \mathrm{~kg} / \mathrm{cm}^{2}$ で， $G_{p}$ は実測值とはとんど一致する. また $G<100>/ G<111>20^{\circ} \mathrm{C}$ で $2.36,50^{\circ} \mathrm{C}$ で 2.38 て昷 度とと乎に増加する攧向にある。

(8) 3 主要軸方向括よび多結晶体に打ける郕性率の $0^{\circ} \sim$ $40^{\circ} \mathrm{C}$ の平均温度係数はそれどれ $g_{<100>}=-12.73 \times 10^{-5}$, $g_{<110>}=-29.27 \times 10^{-5}, g_{<111>}=-29.38 \times 10^{-5}$ 牤よび $g_{p}=$ $-28.40 \times 10^{-5}$ でする.

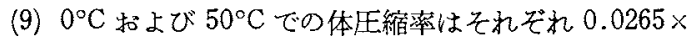
$10^{-5} \mathrm{~cm}^{2} / \mathrm{kg}, 0.0276 \times 10^{-5} \mathrm{~cm}^{2} / \mathrm{kg}$ である.

(10) $\langle 100\rangle,\langle 110\rangle,\langle 111\rangle$ に近い方向执よび多結 晶体に対する引張強さは $20^{\circ} \mathrm{C}$ でそれぞれ $40.80,34.00$, 45.27 执よび $35.70 \mathrm{~kg} / \mathrm{mm}^{2}$ でする。

終りに，本研究遂行中装置の使用に多大の便宜をはから れた東北大学金属材料研究所の菅井富氏, 同研究所共通 試料室の各位ならびに測定に協力された電気磁気材料研究 所の沢谷炤八氏に厚く感謝する。 